\title{
PENGARUH RASIO KEUANGAN TERHADAP KEBIJAKAN DEVIDEN (STUDI PADA PERUSAHAAN REAL ESTATE DAN PROPERTY YANG TERDAFTAR DI BURSA EFEK INDONESIA)
}

\author{
Lisma Aniyati \\ lisma.hidayat@gmail.com \\ Universitas Ahmad Dahlan \\ Hendro Setyono \\ hendro.setyono@yahoo.com \\ Universitas Ahmad Dahlan
}

\begin{abstract}
ABSTRAK
This research aimed to analyze and test the effect of financial ratios of the dividend policy on the real estate and properties listed in the Indonesia Stock Exchange. The independent variables is used Return On Investment (ROI), Debt to Total Assets (DTA), Earning Per Share (EPS), and Total Asset Turnover (TATO). Another dependent variable is used dividend Payout Ratio (DPR). The population of this research is 50 companies. There are from the real estate companies and properties which registered in Indonesia Stock Exchange in the period 2012-2014. Because not all members of the population is meet the criteria, the sampling method is used purposive sampling method there are 9 samples. The analytical method are used the classic assumption test and regression test. Based on the survey results showing that from partially there is only DTA variables were not significantly influent to the dividend policy on real estatecompany and properties which registered in Indonesia Stock Exchange. Another variable are ROI, EPS, and TATO were significant effect to the dividend policy on real estate and properties which registered in Indonesia Stock Exchange. The results simultaneous test showed the ROI, DTA, EPS, and TATO variables has an influence to the real estate company and properties which registered in indonesian Stock Exchange. The higher coefficient of determination is $49.10 \%$.
\end{abstract}

Keywords: Return On Investment; Debt to Total Assets; Earning Per Share; Total Asset Turnover; Dividend Payout Ratio.

\begin{tabular}{l}
\hline \multicolumn{3}{c}{ PENDAHULUAN } \\
Pada saat ini, dunia bisnis sering \\
kali menghadapi suatu ketidakpastian. \\
Tingkat ketidakpastian ini membuat \\
perusahaan memilih investasi dengan \\
tingkat risiko yang minimal. Perusahaan \\
memutuskan untuk melakukan investasi \\
saat ini dengan harapan akan \\
mendapatkan keuntungan yang cukup di \\
masa mendatang (Sartono, 2000). Bagi \\
seorang calon investor yang rasional, \\
perhatiannya akan diarahkan pada tingkat \\
pengembalian (return) investasi dan \\
investasi yang dipilih
\end{tabular}

adalah yang menjanjikan return tertinggi dengan risiko tertentu. Tingkat pengembalian investasi dapat diprediksi dari laporan keuangan perusahaan. Laporan keuangan pada umumnya terdiri dari neraca, laporan laba rugi serta laporan perubahan modal (Munawir, 2007). Informasi tersebut akan memberikan gambaran mengenai kondisi, prospek ekonomi, rencana investasi, serta ramalan laba dan dividen yang akan dijadikan dasar dalam pembuatan keputusan rasional mengenairisiko dan nilai saham yang ditawarkan perusahaan. Laporan keuangan 
yang dibuat oleh perusahaan disajikan sebagai informasi meliputi posisi keuangan perusahaan, laporan kinerja, perubahan posisikeuangan dan laporan arus kas yang bermanfaat para pemakainya, baik investor maupun kreditor .

Adapun informasi keuangan yang disampaikan antara lain: informasi profitabilitas, likuiditas, aktivitas dan rasio solvabilitas. Profitabilitas merupakan salah satu indikator penting untuk menilai suatu perusahaan. Profitabilitas selain digunakan untuk mengukur kemampuan perusahaan dalam menghasilkan laba juga untuk mengetahui efektifitas perusahaan dalam mengelola sumber-sumber yang dimilikinya. Selain profitabilitas, perusahaan membutuhkan informasi likuiditas, yaitu kemampuan perusahaan dalam membayar hutang-hutangnya. Semakin tinggi likuiditas maka semakin besar kemampuan perusahaan dalam membayar hutangnya.

Likuiditas sangat penting bagi kreditor jangka panjang dan para pemegang saham untuk mengetahui prospek dari deviden dan pembayaran bunga di masa yang akan datang. Kemudian rasio aktivitas atau rasio perputaran asset merupakan rasio yang paling umum digunakan dengan menghubungkan penjualan bersih dengan aset bersih. Rasio perputaran aset yang tinggi mengindikasikan pengelolaan aset yang efisien, sedangkan rasio perputaran aset yang rendah mengindikasikan pengelolaan aset yang kurang efisien. Rasio solvabilitas digunakan untuk mengetahui apakah perusahaan sudah menggunakan secara baik atau menguntungkan dengan menjaga keseimbangan antara modal yang berasal dari pinjaman yang berasal dari pemilik (Munawir, 2007).

Penelitian yang dilakukan oleh Priono (2006) menunjukkan terdapat pengaruh yang signifikan antara return on investment, debt to total assets dan earning per share terhadap dividen per share. Selanjutnya penelitian yang dilakukan oleh Utami (2008) menunjukkan earning per share dan total asset turnover berpengaruh signifikan terhadap kebijakan dividend. Penelitian ini melengkapi penelitian Priono (2006) yang belum memasukkan unsur total asset turnover yang sudah diteliti oleh Utami (2008) untuk mengetahui secara meyakinkan pengaruh secara bersama-sama maupun parsial berbagai variabel yang diteliti. Hal ini perlu dilakukan karena perkembangan perusahaan yang go public di Bursa Efek Indonesia sangat dinamis, sehingga setiap tahun mengalami perubahan. Adanya perubahan ini perlu dianalisis konsistensi pengaruhnya terhadap kebijakan dividen, sehingga menjadi dasar bagi investor untuk memutuskan investasi dengan harapan memperoleh keuntungan dari perusahaan yang membagi dividen di masa yang akan datang.

Kebijakan deviden merupakan salah satu kebijakan dalam perusahaan yang harus diperhatikan dan dipertimbangkan secara seksama. Dalam kebijakan deviden ditentukan jumlah laba yang dapat dibagikan kepada para pemegang saham (deviden) dan alokasi laba yang dapat ditahan perusahaan. Semakin besar laba yang ditahan, semakin kecil laba yang akan dibagikan pada para pemegang saham. Dalam pengalokasian laba tersebut timbulah berbagai masalah yang dihadapi.

Prihantoro (2003) mengungkapkan para pemegang saham mempunyaitujuan utama untuk meningkatkan kesejahteraannya yaitu mengharapkan pengembalian dalam bentuk deviden maupun capital gain. Di lain pihak, perusahaan juga mengharapkan adanya pertumbuhan secara terus menerus untuk mempertahankan kelangsungan hidupnya.

Darman (2008) mengungkapkan manajer sebagai agen yang diberi amanat oleh pemegang saham untuk membuat keputusan yang dapat memaksimumkan kekayaan pemegang saham telah menciptakan konflik potensial atas 
kepentingan masing masing pihak yang disebut dengan konflik keagenan (agency conflict) dalam konteks teori keagenan (agency theory). Konflik agency muncul sebagai akibat adanya pemisahan antara kepemilikan dan pengendalian perusahaan. Konflik kepentingan tidak hanya terjadi antara pemegang saham dengan manajer, konflik kepentingan dapat terjadi antara pemegang saham dengan kreditor. Pada umumnya para pemegang saham menginginkan proyek dengan expected return yang tinggi. Sayangnya dalam dunia nyata, investasi yang memberikan return yang tinggi, resikonya juga tinggi (Sartono, 2001). Tingginya resiko akan menyebabkan kreditur ikut menanggung resiko. Bagi para investor faktor stabilitas deviden akan lebih menarik daripada dividend payout ratio yang tinggi. Stabilitas di sini dalam arti tetap memperhatikan tingkat pertumbuhan perusahaan, yang ditunjukkan oleh koefisien arah yang positif. Bagi investor pembayaran deviden yang stabil merupakan indikator prospek perusahaan yang stabil pula dengan demikian resiko perusahaan juga relatif lebih rendah dibandingkan dengan perusahaan dengan perusahaan yang membayar deviden tidak stabil (Sartono, 2001).

Namun, besar kecilnya deviden yang dibayarkan kepada pemegang saham tergantung pada kebijakan deviden masing-masing perusahaan dan dilakukan berdasarkan pertimbangan berbagai faktor. Berdasarkan faktor-faktor yang dipertimbangkan oleh manajemen dan keputusan investor yang didasarkan pada kinerja keuangan maka penelitian ini mengidentifikasi variabel-variabel yang diduga berpengaruh terhadap rasio pembayaran deviden. Likuiditas perusahaan merupakan pertimbangan utama dalam banyak kebijakan deviden. Karena deviden bagi perusahaan merupakan kas keluar, maka semakin besar posisi kas dan likuiditas perusahaan secara keseluruhan akan semakin besar pula kemampuan perusahaan untuk membayar deviden (Sartono, 2001).

Suharli (2007) mengungkapkan hanya perusahaan yang memiliki likuiditas baik yang akan membagikan labanya kepada pemegang saham dalam bentuk tunai. Penelitian ini memproksikan likuiditas perusahaan dengan Current Ratio. Sumarto (2007) mengungkapkan dengan mengkaitkan kas dan aktiva lancar dapat memberikan ukuran likuiditas yang cepat dan mudah digunakan oleh suatu perusahaan.

Tujuan dari penelitian ini di antaranya:

1. Untuk menganalis pengaruh Return on investment terhadap kebijakan dividen pada perusahaan real estate dan property yang terdaftar di Bursa Efek Indonesia periode 2012-2104.

2. Untuk menganalis pengaruh Debt to total assets terhadap kebijakan dividen pada perusahaan real estate dan property yang terdaftar di Bursa Efek Indonesia periode 2012-2104.

3. Untuk menganalis pengaruh Earning per share terhadap kebijakan dividen pada perusahaan real estate dan property yang terdaftar di Bursa Efek Indonesia periode 2012-2104.

4. Untuk menganalis pengaruh Total asset turnover terhadap kebijakan dividen pada perusahaan real estate dan property yang terdaftar di Bursa Efek Indonesia periode 2012-2104.

5. Untuk menganalisis pengaruh Return on investment, Debt to total assets, Earning per share, Total asset turnover terhadap kebijakan dividen secara simultan pada perusahaan real estate dan property yang terdaftar di Bursa Efek Indonesia periode 2012-2104. 


\section{REVIEW LITERATUR DAN HIPOTESIS}

\section{Landasan Teori}

1. Kebijakan Deviden

Kebijakan deviden (dividend policy) adalah keputusan apakah laba yang diperoleh perusahaan akan dibagikan kepada pemegang saham sebagai deviden atau akan ditahan dalam bentuk laba ditahan guna pembiayaan investasi dimasa datang. Apabila perusahaan memilih untuk membagikan laba sebagai deviden, maka akan mengurangi laba yang ditahan dan selanjutnya akan mengurangi total sumber dana intern atau internal financing (Sartono, 2000).

\section{Return On Investment}

Rasio profitabilitas yang digunakan adalah return on investment. Return on investment menunjukkan kemampuan perusahaan menghasilkan laba dari aktiva yang dipergunakan.

\section{Debt to Total Assets}

Rasio solvabilitas yang digunakan adalah rasio utang atau Debt to Total Asset Ratio. Rasio ini memperlihatkan proporsi antara kewajiban yang dimiliki dan seluruh kekayaan yang dimiliki. Semakin tinggi hasil persentasenya, cenderung semakin besar risiko keuangannya bagi kreditor maupun pemegang saham.

\section{Earning Per Share}

Pendapatan per lembar saham (earning per share) merupakan total keuntungan yang diperoleh investor untuk setiap lembar sahamnya. Total keuntungan tersebut diukur dari rasio antara laba bersih setelah pajak (earnings after tax/EAT) terhadap jumlah lembar saham yang beredar (outstanding share).
5. Total Assets Turnover

Rasio perputaran aset merupakan rasio keuangan yang digunakan untuk mengukur intensitas perusahaan dalam menggunakan asetnya.

\section{Penelitian Terdahulu}

Penelitian oleh Toni Setiawan (2007) meneliti tentang analisis pengaruh factor fundamental dan teknikal terhadap deviden indeks LQ 45 yang tercatat di Bursa Efek Jakarta (periode Februari 2002-Januari 2006), menyimpulkan bahwa secara simultan factor fundamental dan teknikal berpengaruh signifikan terhadap deviden. Sedangkan secara parsial variabel fundamental emiten yaitu : PER, EPS, PBV, DER, OPM, NPM, TATO, dan ROI dan variabel fundamental ekonomi yaitu: Suku Bunga SBI berpengaruh signifikan terhadap deviden.

Kania dan Bacon (2005) dalam penelitiannya yang berjudul "What factor motivate the corporate dividend decision", menghasilkan kesimpulan bahwa hanya variabel EPS yang memiliki pengaruh positif signifikan, sedangkan variabel ROE, sales growth, beta, CR, DTA, insider ownership, institutional ownership dan capital spending memiliki pengaruh negatif signifikan terhadap DPR.

\section{Hipotesis}

H1: Return On Investment berpengaruh terhadap kebijakan dividen.

H2: Debt To Total Asset berpengaruh terhadap kebijakan dividen.

H3: Earning Per Share berpengaruh terhadap kebijakan dividen.

H4: Total Asset Turn Over berpengaruh terhadap kebijakan dividen.

H5: Return on investment, Debt to total assets, Earning per share, Total asset turnover berpengaruh secara simultan terhadap kebijakan dividen. 


\section{METODE PENELITIAN}

\section{Populasi dan Sampel}

Populasi dalam penelitian ini adalah seluruh perusahaan real estate dan property yang terdaftar di Bursa Efek Indonesia dalam periode 2012-2104. Jumlah populasi dalam penelitian ini adalah 50 perusahaan real estate dan property. Pengambilan sampel dilakukan dengan metode purposive sampling dengan tujuan untuk mendapatkan sampel yang representatif dengan kriteria sebagai berikut:

1. Perusahaan real estate dan property yang terdaftar di Bursa Efek Indonesia periode 2012-2014.

2. Perusahaan tersebut membagikan deviden setiap periode pengamatan yaitu periode 2012-2014.

3. Perusahaan tersebut selalu menyajikan laporan keuangan setiap periode pengamatan.

Rincian Perolehan Sampel

\begin{tabular}{|c|c|}
\hline Kriteria Pemillhan Sampel & Jumlah \\
\hline Perusahaan yang terdaftar di BEI & 50 \\
\hline $\begin{array}{l}\text { Perusahaan yang tidak menyajikan } \text { Ansul } \\
\end{array}$ & (5) \\
\hline 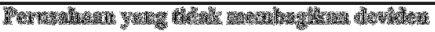 & (36) \\
\hline 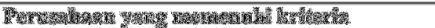 & 9 \\
\hline
\end{tabular}

\section{Definisi Operasional}

1. Variabel Independen

a. Return On Invesment

Return on invesment adalah kemampuan perusahaan menghasilkan laba dari aktiva yang di pergunakan. Rumus yang digunakan untuk mengukur Return on invesment adalah:

Return On Invesment $=$ Laba Setelah Pajak

Total Aktiva

b. Debt to Total Assets

Debt to total assets adalah rasio yang mengukur total utang yang digunakan untuk membiayai aktiva dalam aktivitas operasional perusahaan. Rumus yang digunakan untuk mengukur debt to total assets adalah:

Dept to Total Assets $=$ Total Hutang

Total Aktiva

\section{c. Earning Per Share}

Pendapatan per lembar saham (earning per share) merupakan total keuntungan yang diperoleh investor untuk setiap lembar sahamnya. Rumus yang digunakan untuk mengukur earning per share adalah:

Earning Per Share $=$ Laba Setelah Pajak - Deviden

$$
\text { Jumlah Saham }
$$

d. Total Asset Turnover

Total Asset Turnover adalah rasio yang mengukur kemampuan dana dalam aktiva yang digunakan untuk investasi dalam memperoleh pendapatan. Rumus yang digunakan untuk mengukur Total Asset Turnover adalah:

$$
\text { Total Asset Turnover }=\frac{\text { Sales }}{\text { Total Aset }}
$$

\section{Variabel Dependen}

Variabel yang digunakan dalam penelitian ini adalah Dividend Payout Ratio. Dalam penelitian ini kebijakan dividen diproksikan dengan Dividend Payout Ratio (DPR), karena DPR dapat menggambarkan perilaku oportunistik manajerial yaitu dengan melihat berapa besar keuntungan yang dibagikan kepada shareholders sebagai dividen dan berapa yang disimpan di perusahaan. Rumus dividend payout ratio adalah sebagai berikut:

$$
\text { Devidend Payout Ratio }=\frac{\text { Dividen per Lembar Saham }}{\text { Laba per Lembar Saham }}
$$




\section{Uji Instrumen}

1. Uji Asumsi Klasik

a. Normalitas

Uji normalitas bertujuan untuk menguji apakah dalam suatu model regresi linier variabel terikat dan variabel bebas keduanya mempunyai distribusi normal atau tidak. Model regresi yang baik adalah memiliki distribusi data normal atau mendekati normal. Cara untuk melihat normalitas adalah dengan melihat histogram yang membandingkan antara data observasi dengan distribusi yang mendekati distribusi normal. Namun demikian dengan hanya dengan melihat histogram, hal ini dapat menyesatkan khususnya untuk sample yang kecil jumlahnya.

Metode yang lebih handal adalah dengan melihat normal probability plot yang membandingkan distribusi komulatif dari data sesungguhnya dengan distribusi kumulatif dari distribusi normal. Distribusi normal akan membentuk satu garis lurus diagonal, dan plooting data akan dibandingkan dengan garis diagonal. Jika distribusi data adalah normal, maka garis yang menggambarkan data sesungguhnya akan mengikuti garis diagonalnya (Ghozali, 2001). Pedoman pengambilan keputusan:

Nilai Sig atau signifikansi atau nilai probabilitas $<0,05$. Distribusi adalah tidak normal.

Nilai Sig atau signifikansi atau nilai probabilitas $>0,05$. Distribusi adalah normal.

b. Autokorelasi

Uji autokorelasi bertujuan untuk menguji apakah dalam suatu model regresi linier ada korelasi antara kesalahan pada periode $\mathrm{t}$ dengan periode t-1 (sebelumnya). Jika terjadi korelasi maka dinamakan ada problem autokorelasi (Ghozali, 2001). Untuk menguji ada tidaknya gejala autokorelasi maka dapat dideteksi dengan uji Durbin-Waston (DW test). Menurut keputusan ada tidaknya autokorelasi dilihat dari bila nilai DW terletak diantara nilai du dan 4-du $($ du $<$ DW $<4-d u)$, maka berarti tidak ada autokorelasi. Selain menggunakan uji DW, uji RUN (Run Test) dapat pula digunakan untuk menguji apakah antar residual terdapat korelasi yang tinggi. Jika antar residual tidak terdapat hubungan korelasi maka dikatakan bahwa residual adalah acak atau random.

c. Heteroskedastisitas

Uji heteroskedastisitas bertujuan menguji apakah dalam model regresi terjadi ketidaksamaan variance dari residual satu pengamatan ke pengamatan lain. Jika variance dari residual satu pengamatan ke pengamatan lain tetap, maka disebut homoskedastisitas dan jika berbeda disebut heteroskedastisitas. Model regresi yang baik adalah homoskedastisitas atau tidak terjadi heteroskedastisitas. Salah satu cara mendeteksi ada tidaknya heteroskedastisitas dengan melihat grafik Plot antara nilai prediksi variabel terikat yaitu ZPRED dengan residualnya SRESID. Deteksi ada tidaknya heteroskedastisitas dengan melihat ada tidaknya pola tertentu pada grafik scatter plot antara SRESID dan ZPRED dimana sumbu $Y$ adalah $\mathrm{Y}$ yang telah diprediksi, dan sumbu $\mathrm{X}$ adalah residual ( $\mathrm{Y}$ prediksi - Y sesungguhnya) yang telah di studentized (Ghozali, 
2001). Adapun dasar analisisnya sebagai berikut:

1) Jika ada pola tertentu seperti titiktitik yang yang ada membentuk pola tertentu yang teratur (bergelombang, melebar kemudian menyempit), maka mengindikasikan telah terjadi heteroskedastisitas.

2) Jika tidak ada pola yang jelas, serta titik-titik menyebar diatas dan dibawah angka 0 pada sumbu Y, maka tidak terjadi heteroskedastisitas. Selain itu, ujiheterodeksitas dapat dilakukan dengan cara Uji Glejser, yaitu dengan mengabsolutkan nilai residual kemudian meregresikan dengan variable independen. Jika variabel independen signifikan secara statistik mempengaruhi variabel dependen maka ada indikasi terjadi heterodeksitas.

d. Multikolinieritas

Uji multikolinearitas digunakan untuk mengetahui ada tidaknya hubungan yang berarti antara masing-masing variabel bebas dalam model regresi. Untuk mengetahui ada tidaknya multikolinearitas di dalam model regresi sebagai berikut:

1) Nilai R2 yang dihasilkan oleh suatu estimasi model regresi empiris sangat tinggi, tetapi secara individual variabel bebas banyak yang tidak signifikan mempengaruhi variabel terikat.

2) Menganalisis matrik korelasi variabel-variabel bebas. Jika antar variable bebas ada korelasi yang cukup tinggi (umumnya di atas 0,90), maka hal ini merupakan indikasi adanya multikolinearitas.
3) Melihat nilai tolerance dan variance inflation factor (VIF). Nilai yang umum dipakai untuk menunjukkan adanya multikolinearitas adalah nilai tolerance $<0,10$ atau sama dengan nilai VIF > 10 .

\section{Teknik Analisis Data}

1. Analisis Regresi Berganda $\mathrm{DPR}=\mathrm{a}+\mathrm{b} 1(\mathrm{ROI})+\mathrm{b} 2(\mathrm{DTA})+$ b3(EPS) + b4(TATO)

Dimana :

$\mathrm{Y}=$ Deviden payout ratio

$\alpha=$ Konstanta

$\beta 1=$ Koefisien regresi ROI

$\beta 2=$ Koefisien regresi DTA

$\beta 3=$ Koefisien regresi EPS

$\beta 4=$ Koefisien regresi TATO

$\mathrm{X} 1$ = Variabel ROI

$\mathrm{X} 2=$ Variabel DTA

$\mathrm{X} 3=$ Variabel DTA

$\mathrm{X} 4=$ Variabel TATO

\section{Uji Hipotesis}

\section{Uji Parsial (Uji T)}

Uji statistik $t$ pada dasarnya menunjukkan seberapa jauh pengaruh satuvariabel bebas secara individual dalam menerangkan variasi variabel terikat. Hipotesis nol (Ho) yang hendak diuji adalah apakah suatu parameter (bi) sama dengan nol, atau : Ho : bi $=0$ Artinya suatu variabel bebas bukan merupakan penjelas yang signifikan terhadap variabel terikat. Hipotesis alternatifnya (Ha) parameter suatu variable tidak sama dengan nol, atau Ha : bi $\neq 0$ Artinya variabel tersebut merupakan variabel penjelas yang signifikan terhadap variabel terikat.

\section{Uji Simultan (Uji F)}

Uji statistik $F$ pada dasarnya menunjukkan apakah semua variabel bebas yang dimasukkan dalam model mempunyai pengaruh secara bersamasama terhadap variabel terikat. Hipotesis nol (Ho) yang hendak diuji 
adalah apakah parameter dalam model sama dengan nol, atau : Ho : b1 = b2 = $\ldots \ldots \ldots=b k=0$ Artinya, apakah semua variabel bebas bukan merupakan penjelas yang signifikan terhadap variabel terikat. Hipotesis alternatifnya (Ha) tidak semua parameter secara simultan sama dengan nol, atau: Ha : $\mathrm{b} 1 \neq \mathrm{b} 2 \neq \ldots . . . \ldots \neq \mathrm{bk} \neq 0$ Artinya, semua variabel bebas secara simultan mempunyai penjelas yang signifikan terhadap variabel terikat.

\section{Uji Koefisien Determinasi}

Koefisien determinasi (R2) pada intinya mengukur seberapa jauh kemampuan model dalam menerangkan variasi variabel terikat. Nilai koefisien determinasi adalah antara nol dan satu. Nilai koefisien determinasi yang kecil berarti kemampuan variabel-variabel bebas dalam menjelaskan variasi variabel terikat amat terbatas dan sebaliknya.

\section{HASIL PENELITIAN DAN PEMBAHASAN}

\section{Hasil Penelitian}

1. Hasil Uji Asumsi Klasik

a. Normalitas

Uji Normalitas dengan Uji One-Sample Kolmogoror Smirnov

\begin{tabular}{|l|c|}
\hline & Unstandardized Residual \\
\hline AsympSSig.(2t-ailed) & 0,965 \\
\hline
\end{tabular}

Uji One-Sample KlomogorovSmirnov digunakan untuk mengetahui normalitas. Hasil pengujian disajikan pada tabel di atas menunjukkan uji normalitas mempunyai tingkat signifikansi sebesar 0,965. Nilai signifikansi tersebut di atas 0,05 . Hal ini berarti data yang digunakan dalam penelitian ini berdistribusi normal. b. Autokorelasi

Hasil uji Durbin-Watson

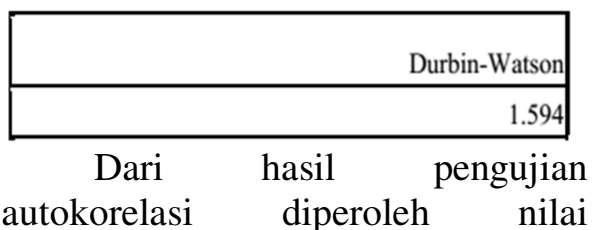

koefisien Durbin Watson sebesar 1,594. Nilai dibandingkan nilai Durbin Watson tabel untuk $\mathrm{n}=27$ dan $\mathrm{k}=4$ dengan $(\alpha=0,05)$ maka nilai $\mathrm{dU}=1,752$ dan $\mathrm{dL}=1,083$. Berdasarkan nilai $\mathrm{dU}$ dan $\mathrm{dL}$ tersebut selanjutnya dihitung nilai $\mathrm{U}$ $-\mathrm{dU}=4-2,588=1,412$, sedangkan nilai $\mathrm{U}-\mathrm{dL}=4-$ $0,296=3,704$. Berdasarkan tabel di atas dapat diketahui nilai uji Durbin Watson berada diantara dL dan dU, artinya tidak terdapat kesimpulan hasil uji autokorelasi, atau berada di daerah keragu-raguan.

c. Heteroskedastisitas

Hasil Uji Heteroskedastisidas

\begin{tabular}{|l|r|}
\hline Model & Sig. \\
\hline (Constant) & .389 \\
\hline X1_ROI & .664 \\
\hline X2_DTA & .296 \\
\hline X3_EPS & .527 \\
\hline X4_TATO & .583 \\
\hline \multicolumn{2}{|c|}{ Uji } \\
\hline
\end{tabular}

digunakan untuk mengetahui ada atau tidaknya penyimpangan asumsi klasik heteroskedastisitas yaitu adanya ketidaksamaan varian dari residual untuk semua pengamatan pada model regresi. Penelitian ini menggunakan uji Glesjer untuk mendeteksi ada tidaknya heteroskedastisitas.

Hasilnya dapat dilihat pada tabel di atas yang menunjukkan bahwa nilai signifikansinya lebih dari 0,05. Dengan demikian dapat diartikan variabel penelitian yang terdiri atas return on investment, debt to total assets, earning per share dan total assets turnover tidak 
terjadi masalah heteroskedastisitas pada model regresi.

d. Multikolinieritas

\begin{tabular}{|c|c|c|}
\hline Voriabel & he & 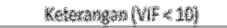 \\
\hline 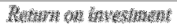 & 2,448 & Tidtak tergadi rmultholinearitus \\
\hline dwio tosal aspets & 2098 & 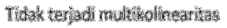 \\
\hline 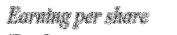 & 2279 & Thtak terjadi nut theolineatias \\
\hline Thtol assot turnower & 1,172 & 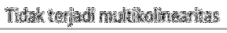 \\
\hline
\end{tabular}

menunjukkan tidak ada nilai variabel independen yang memiliki nilai tolerance kurang dari 0,10 yang berarti tidak ada korelasi antara variabel independen yang nilainya lebih dari 95 persen. Hasil perhitungan nilai Variance Inflation Factor (VIF) juga menunjukkan hal yang sama tidak ada satu variabel independen yang memiliki VIF lebih dari 10. Jadi dapat disimpulkan bahwa tidak ada multikolinearitas antara variabel independen dalam model regresi.

2. Hasil Uji Regresi Linier Berganda Hasil Output Regresi Linier Berganda

\begin{tabular}{|l|r|}
\hline \multicolumn{1}{|c|}{ MODEL } & \multicolumn{1}{|c|}{ B } \\
\hline 1 (Constant) & 3.908 \\
\hline X1_ROI & .851 \\
\hline X2_DTA & .032 \\
\hline X3_EPS & -.019 \\
\hline X4_TATO & -17.449 \\
\hline
\end{tabular}

$\mathrm{Y}=3.908+0.851 \mathrm{X} 1+0.032 \mathrm{X} 2-$ 0.019 X3 - 17.449 X4

Maka dengan demikian dapat dianalisis sebagai berikut:

a. Nilai konstanta adalah positif sebesar 3,908 mengandung arti bahwa jika variable bebas (return on investment, debt to total assets, earning per share dan total asset turnover) bernilai nol maka dividend payout ratio perusahaan real estate di Bursa Efek Indonesia adalah 3,908.

b. Nilai koefisien regresi variabel return on investment sebesar 0,851 . Nilai koefisien regresi yang positif tersebut berarti jika variabel debt to total assets, Earning per share dan total asset turnover bernilai nol, maka kenaikan Return on investment satu persen akan berpengaruh terhadap peningkatan dividend payout ratio sebesar 0,851 persen.

c. Nilai koefisien regresi debt to total assets sebesar 0,032. Nilai koefisien regresi yang positif tersebut berarti jika variabel Return on investment, Earning per share dan total asset turnover bernilai nol, maka kenaikan debt to total assets satu kali akan berpengaruh terhadap peningkatan Dividend payout ratio sebesar 0,032 persen.

d. Nilai koefisien regresi Earning per share sebesar -0,019. Nilai koefisien regresi yang negatif tersebut berarti jika variabel return on investement, debt to total assets, dan total asset turnover bernilai nol, maka kenaikan Earning per share rupiah akan berpengaruh terhadap penurunan dividend payout ratio sebesar 0,019 persen.

e. Nilai koefisien regresi total asset turnover sebesar -17,449. Nilai koefisien regresi yang negatif tersebut berarti jika variabel return on investement, debt to total assets, dan earning per share bernilai nol, maka kenaikan total asset turnover satu kali akan berpengaruh terhadap penurunan dividend payout ratio sebesar 17,449 persen.

3. Hasil Uji Parsial (Uji T)

\begin{tabular}{lccc}
\multicolumn{4}{c}{ Hasil Regresi Uji- t } \\
\hline \multicolumn{1}{c}{ Variabel } & t hitung & $\mathrm{t}$ tabel & $\mathrm{Sig}$ \\
\hline Return on investment & 3.974 & 1,713 & 0.001 \\
debt to total assets & 0.915 & 1,713 & 0.370 \\
Earning per share & -2.800 & 1,713 & 0.010 \\
Total asset turnover & -2.849 & 1,713 & 0.009 \\
\hline
\end{tabular}

Dari hasil perhitungan uji secara parsial yang disajikan pada tabel di atas diperoleh nilai t hitung variable return on investment sebesar 3,974, lebih besar dari t tabel 1,713 dengan nilai signifikansi 0,001 atau lebih kecil dari nilai alphanya $(\alpha=0,05)$, berarti terdapat pengaruh positif signifikan variabel Return on investment terhadap variabel dividend payout ratio. 
Menurut perhitungan, $\mathrm{t}$ hitung variabel debt to total assets sebesar 0,915 , lebih kecil dari -t tabel 1,713 dengan nilai signifikansi 0,370 atau lebih besar dari nilai alphanya $(\alpha=$ $0,05)$, berarti terdapat tidak pengaruh signifikan variabel debt to total assets terhadap variabel dividend payout ratio.

Dari perhitungan diperoleh $\mathrm{t}$ hitung variabel earning per share sebesar -2,800, lebih besar dari $\mathrm{t}$ tabel $-1,713$ dengan nilai signifikansi 0,010, atau lebih kesil dari nilai alphanya $(\alpha=0,05)$, berarti terdapat pengaruh negatif yang signifikan variabel earning per share terhadap variabel dividend payout ratio.

Menurut perhitungan, $\mathrm{t}$ hitung variabel total asset turnover sebesar 2,849, lebih besar dari t table 1,713 dengan nilai signifikansi 0,009 atau lebih kecil dari nilai alphanya $(\alpha=$ $0,05)$, berarti terdapat pengaruh negatif signifikan variabel total aset turnover terhadap variabel dividend payout ratio.

4. Hasil Uji Simultan (Uji F)

Hasil Regresi Uji-F

\begin{tabular}{|c|c|c|c|}
\hline \multicolumn{4}{|c|}{ ANOVA $^{b}$} \\
\hline Model & Df & $\mathrm{F}$ & Sig. \\
\hline Regression & 4 & 5.305 & $.004^{2}$ \\
\hline Residual & 22 & & \\
\hline Total & 26 & & \\
\hline
\end{tabular}

Dari hasil perhitungan yang disajikan pada tabel di atas diperoleh nilai $\mathrm{F}$ hitung sebesar 5,305, lebih besar dari $\mathrm{f}$ tabel 3,03 dengan nilai signifikansi sebesar 0,004 atau lebih kecil dari nilai alphanya $(\alpha=0,05)$. Hal ini menunjukkan bahwa return on investment, debt to total assets, earning per share dan total asset turnover secara bersama-sama berpengaruh terhadap Dividend payout ratio.
5. Hasil Uji Koefisien Determinasi Hasil Output R-Square

\begin{tabular}{|r|}
\hline R Square \\
\hline \\
\end{tabular}

Dari persamaan regresi, diperoleh koefisien determinasi $\left(\mathrm{R}^{2}\right)$ sebesar 0,49. Hal ini berarti perubahan dividend Payout Ratio 49,10 persen dipengaruhi oleh variasi perubahan variabel return on investment, debt to total assets, earning per share dan total asset turnover, sedangkan 50,90 persen dipengaruhi variabel lain yang tidak diteliti.

\section{Pembahasan}

1. Pengaruh return on investment terhadap kebijakan dividend perusahaan real estatedan properti di Bursa Efek Indonesia. Berdasarkan hasil analisis regresi linier berganda dan uji hipotesis menunjukkan bahwa return on investment berpengaruh positif terhadap dividend payout ratio perusahaan real estate dan properti di Bursa Efek Indonesia. Semakin meningkat return on investment, maka semakin besar dividend payout ratio-nya. Hasil penelitian sesuai dengan hasil penelitian yang dilakukan oleh Priono (2006) yang membuktikan bahwa return on investment berpengaruh siginifikan terhadap devidend payout ratio.

Profitabilitas yang dalam penelitian ini diproksikan kepada return on investment merupakan salah satu indikator yang penting untuk menilai suatu perusahaan. Profitabilitas selain digunakan untuk mengukur kemampuan perusahaan dalam menghasilkan laba juga untuk mengetahui efektifitas perusahaan dalam mengelola sumber-sumber yang dimilikinya. Rasio profitabilitas mengukur keberhasilan menajemen sebagaimana ditunjukkan oleh laba yang dihasilkan oleh penjualan dan 
investasi. Dengan tingkat profitabilitas yang tinggi berarti perusahaan akan beroperasi pada tingkat biaya rendah yang akhirnya akan menghasilkan laba yang tinggi. Seorang calon investor perlu melihat ROI suatu perusahaan sebelum memutuskan melakukan investasi supaya dapat mengetahui seberapa banyak yang akan dihasilkan dari investasi yang dilakukannya (Sitepu, 2010). Semakin tinggi tingkat laba yang diperoleh, maka kemampuan perusahaan untuk membayar dividen juga akan semakin tinggi dan harga saham perusahaan akan semakin meningkat.

2. Pengaruh debt to total assets terhadap dividend payout ratio perusahaan real estate dan properti di Bursa Efek Indonesia. Berdasarkan hasil analisis regresi linier berganda dan uji hipotesis menunjukkan bahwa debt to total assets tidak berpengaruh signifikan terhadap dividend payout ratio perusahaan real estate dan property di Bursa Efek Indonesia. Semakin menurun debt to total assets maka semakin besar dividend payout rationya. Hasil penelitian tidak sesuai dengan hasil penelitian yang dilakukan oleh Priono (2006) yang membuktikan bahwa debt to total assets berpengaruh signifikan terhadap devidend payout ratio. Debt to total assets (DTA) menunjukkan seberapa besar perusahaan dibiayai oleh utang. Semakin besar rasio ini menunjukkan bahwa semakin besar struktur modal yang berasal dari utang digunakan untuk mendanai ekuitas yang ada, seperti yang dikemukakan oleh Warren et al. (2004) dalam Sitepu (2010) bahwa semakin kecil rasio DTA, semakin baik kemampuan perusahaan untuk dapat bertahan dalam kondisi yang buruk. Rasio DTA yang kecil menunjukkan bahwa perusahaan masih mampu memenuhi kewajibannya kepada kreditur dan memberikan deviden yang lebih besar kepada investor. Penelitian ini menunjukan bahwa total assetturnover secara partial tidak berpengaruh secara signifikan terhadap dividendpayout ratio. Ini dikarenakan perusahaan dari aset yang dimiliki perusahaan tidak berhasil bertahan dalam kondisi yang buruk untuk mendanai ekuitas yang ada yaitu struktur modal yang berasal dari utang.

3. Pengaruh earning per share terhadap dividend payout ratio perusahaan real estate dan property di Bursa Efek Indonesia. Berdasarkan hasil analisis regresi linier berganda dan uji hipotesis menunjukkan bahwa earning per share mempunyai pengaruh negatif yang signifikan terhadap dividend payout ratio perusahaan real estate dan properti di Bursa Efek Indonesia. Peningkatan earning per share berpengaruh secara signifikan negatif terhadap peningkatan dividend payout ratio. Hasil penelitian ini tidak sesuai dengan penelitian yang dilakukan oleh Priono (2006) dan Utami (2008) Earning per share (EPS) merupakan total keuntungan yang diperoleh investor untuk setiap lembar sahamnya. EPS yang besar menunjukkan tingkat laba per saham yang besar dan kemungkinan pembagian dividen yang besar pula.

4. Pengaruh total asset turnover terhadap dividend payout ratio perusahaan real estate dan property di Bursa Efek Indonesia. Berdasarkan hasil analisis regresi linier berganda dan uji hipotesis menunjukkan bahwa total asset turnover mempunyai pengaruh negatif secara signifikan terhadap dividend payout ratio perusahaan real estate dan property di Bursa Efek Indonesia. Peningkatan total asset turnover berpengaruh secara signifikan terhadap peningkatan dividend payout ratio. Hasil penelitian ini sesuai dengan 
hasil penelitian yang dilakukan oleh Priono (2006) dan Utami (2008). Rasio perputaran aset merupakan rasio keuangan yang digunakan untuk mengukur intensitas perusahaan dalam menggunakan asetnya. Ukuran penggunaan aset yang paling relevan adalah penjualan karena penjualan merupakan hal yang penting dalam kaitannya dengan laba. Rasio perputaran aset yang tinggi mengindikasikan pengelolaan aset yang efisien, sedangkan rasio perputaran aset yang rendah mengindikasikan pengelolaan aset yang kurang efisien. Strategi bisnis dan produk perusahaan akan sangat mempengaruhi rasio perputaran asset perusahaan. Kemampuan manajemen untuk mengendalikan aset merupakan hal yang sangat vital dalam menentukan keberhasilan perusahaan. Penelitian ini menunjukkan bahwa total asset turnover secara parsial berpengaruh secara signifikan terhadap dividend payout ratio.

\section{KESIMPULAN DAN SARAN}

\section{Kesimpulan}

1. Return on investment berpengaruh signifikan terhadap dividend payout ratio. Peningkatan return on investment berpengaruh terhadap kenaikan dividend payout ratio pada perusahaan real estate dan property di bursa efek Indonesia. Hal tersebut diketahui dari nilai signifikasi ROI sebesar 0,001 lebih kecil dari alpha 5\%.

2. Debt to total assets tidak berpengaruh signifikan terhadap dividend payout ratio. Peningkatan debt to total asset tidak berpengaruh terhadap kenaikan dividend payout ratio pada perusahaan real estate dan property di bursa efek Indonesia. Hal tersebut diketahui dari nilai signifikasi DTA sebesar 0,370 lebih besar dari alpha $5 \%$.
3. Earning per share berpengaruh signifikan terhadap dividend payout ratio. Peningkatan earning per share berpengaruh terhadap kenaikan dividend payout ratio pada perusahaan real estate dan property di bursa efek Indonesia. Hal tersebut diketahui dari nilai signifikasi EPS sebesar 0,010 lebih kecil dari alpha 5\%.

4. Total asset turnover berpengaruh signifikan terhadap dividend payout ratio. Peningkatan total asset turnover berpengaruh signifikan terhadap kenaikan dividend payout ratio pada perusahaan real estate dan property di bursa efek Indonesia. Hal tersebut diketahui dari nilai signifikasi TATO sebesar 0,009 lebih kecil dari alpha 5\%.

5. Return on investment, Debt to total assets, Earning per share, dan Total asset turnover berpengaruh signifikan secara simultan terhadap devidend payout ratio. Hal tersebut diketahui dari nilai signifikasi 0,004 lebih kecil dari alpha 5\%.

\section{Saran}

1. Diharapkan untuk penelitian selanjutnya menambah variabel independen yang digunakan untuk menilai kinerja keuangan perbankan seperti Kualitas Aktiva Produktif (KAP), Net Interest Margin (NIM), Return in Equity (ROE), Biaya Operasional terhadap Pendapatan Operasional (BOPO), Giro Wajib Minimum (GWM), dan faktor-faktor ekonomi seperti tingkat bunga, inflasi, dan lain sebagainya.

2. Diharapkan untuk peneliti selanjutnya menambah periode penelitian sehingga objek penelitian lebih meluas dan hasil yang diharapkan akan bisa lebih baik lagi. 
3. Diharapkan bagi manajer hendaknya mempertimbangkan informasi yang terkait dengan kinerja keuangan perusahaan real estate dan property terutama Return On Invesment (ROI) pada penelitian ini yang merupakan variabel yang paling berpengaruh signifikan terhadap Dividend payout Ratio (DPR).

4. Bagi investor diharapkan dalam proses pengembalian keputusan, untuk menanam modal atau menyimapan dana, terlebih dahulu harus memperhatikan rasio-rasio yang dominan berpengaruh terhadap dividend payout ratio. Perusahaan real estate dan property di Bursa Efek Indonesia agar lebih memperhatikan efisiensi dan pemakaian assetnya untuk memaksimalkan keuntungan perusahaan pada masa yang akan datang.

\section{DAFTAR PUSTAKA}

Ghozali, Imam. (2001). Aplikasi Analisis Multivariate Dengan Program SPSS. Semarang: Badan Peneliti Universitas Diponegoro.

Kania, Sharon dan Frank W. Bacon. (2005). What Factors Motivate The Corporate Dividend Decision. Journal of Finance, Volume 1, 97, Business Index ASAP, Farmville, VA: Longwood University.

Munawir, S. (2007). Analisa Laporan Keuangan. Yogyakarta: Penerbit Liberty.

Priono, Tesdi. (2006). Analisis pengaruh rasio-rasio keuangan, pertumbuhan asset dan ukuran perusahaan terhadap dividen per share. Tesis. Program Studi Magister Manajemen
Program Pasca Sarjana Universitas Diponegoro.

Sartono, A. (2000). Manajemen Keuangan. Yogyakarta: BPFE.

Sitepu. (2010). Manajemen keuangan. Modul Perkuliahan. Universitas Padjadjaran Bandung.

Suharli, M. (2007). Pengaruh Profitability dan Investment Opportunity Set terhadap Kebijakan Dividen Tunai dengan Likuiditas sebagai Variabel Penguat (Studi pada Perusahaan yang Terdaftar di Bursa Efek Jakarta Periode 2002-2004). Jurnal Akuntansi dan Keuangan Vol.9 No.1 Mei.p. 9-17

Utami, Rizky Pebriani. (2009). Pengaruh rasio keuangan terhadap deviden pada sektor industry manufaktur yang terdaftar di bursa efek Indonesia Tahun 2003-2007. Yogyakarta: Fakultas Ekonomi, Universitas Gunadarma. 